„Bohemistyka” 2019, nr 2, ISSN 1642-9893

Mieczysław BALOWSKI

DOI: $10.14746 /$ bo. 2019.2 .4

Univerzita Adma Mickiewicze v Poznani

\section{Měšek nebo Dago, Dobrava nebo Doubravka - jména prvního polského vladce a jeho české manželky}

\section{Abstract}

The author analyzes the names Mieszko and Dąbrówka / Doubravka in Polish and Czech historical sources. He also refers to contemporary linguistic research, which questions the existence of the name Mieczyslaw in the tenth century, and also the name Dabrówka as the Polish form of the Czech name Doubravka. While the second one is certified in Czech texts and was used in the 10th century at the Czech court, the first is known only from the records of the first Polish chronicles. It is not confirmed by any earlier Latin or German chronicles or other documents from that period.

Autor analyzuje jména Mieszko a Dabrówka/Doubravka v polských a českých historických pramenech. Odkazuje také na současné lingvistické studie, které zpochybňují existenci jména Mieczysław v desátém století a také jména Dąbrówka jako polské podoby českého jména Doubravka. Zatímco druhé je uváděno v českých textech a bylo použito v 10 . století u českého knížecího dvora, první je známo pouze z prvních polských kronik. Není potvrzeno staršími latinskými nebo německými kronikami nebo jinými dokumenty z tohoto období.

Keywords: Czech language, Polish language, onomastika, antroponyma, first names, Mieszko, Doubravka

Klíčová slova: český jazyk, polský jazyk, onomastika, antroponyma, jména, Mieszko, Doubravka

Primární funkcí vlastního jména je odkázat na určitou osobu nebo jednotlivý objekt. Avšak velice zřídka základovým slovem vlastního jména není apelativum, jež má vlastní význam a jež ho pak přenáší na proprium. Tímto nepřímým způsobem také vlastní jména nabývají významu (nejenom označují), což je důležité, když rekonstruujeme původní formu proprií, která se dochovala pouze $\mathrm{v}$ písemné formě, většinou v záznamu velmi nedůkladném. S takovou situací se setkává- me v případě jmen prvního polského knížecího páru. Jméno prvního polského knížete dodnes vzbuzuje mnoho pochybností, podobně jako i antroponymum Dąbrówka, jež je interpretováno několika způsoby. Cílem našeho př́spěvku je popsat, jak jsou jména polského knížete Měška a české kněžny Doubravy ukázána $\mathrm{v}$ tradici a v historických dokladech.

Na chybný odkaz jména Měšek k apelativnímu slovo upozorňuje již Andrzej Bańkowski. Tvrdí, že souhláska [š] ve jménu Měšek vznikla $\mathrm{v}$ důsledku ztráty znělosti a jméno nepochází z apelativa mieszek, ale ze slova mbžeti (kmen mbž- a prrípona -bka), které se vztahuje k pověsti o navrácení zraku Měškovi ve věku jeho 8 let ${ }^{1}$. Na tomto základě polský jazykovědec usoudil, že toto jméno pochází od staropolského slova mieżka čili slepec (od slovesa $m \dot{z} y c ́$, které ve staropolštině znamenalo 'mít oči zavřené'). Kromě toho se domnívá, že všechny historické prameny „neuvádějí toto jméno v původní, národní formě, ale ve verzi latinské, tehdy obligatorní" (Bańkowski 1989, s. 128). Když necháme stranou motiv andělů, který se objevuje v pověsti a který byl pravděpodobně přidán kronikářem Gallem Anonymem s cílem zdưraznit význam Měškova vyvolení Bohem, příběh se zdá být pravdivý. Avšak tuto tezi popírají historikové, kteří jméno polského knížete odvozují z latinského záznamu Mesco, Mesconis. Nicméně ani tento záznam nebyl jediný, který se tehdy objevil.

Przemysław Urbańczyk považuje za nejstarší zápis kronikáře Ibrahima ibn Jakuba z roku 965 a navrhuje jinou jeho interpretaci. Jde o záznam Mashaqqah jako označení knížete Měška (Mishin 1996, s. 184, 187-189). ,, Toto slovo je možné vysvětlit jako 'nevýhoda, obtížnost, rána' nebo právě 'trápení'. Objevuje se ve třetím z pěti obecných pravidel islámského zákona: »trápení bude oslabeno« ( $A l-M a$ -

1 Srov. hasło mieszek w słowniku Bańkowskiego: „MIESZEK 'woreczek, sakiewka' (por. też stp. nazwę osobową Mieszek 1136); měšs p. MIECH. Niesłusznie stąd wywodzono imię ojca Bolesława Chrobrego: Mieszko, spolszczenie łc. Mesco -onis, które ze stp. Mieżka (Misica około 980, Mesca XI-XIV, strus. Mežьka), müž-üka od vb. mbžeti, mb̌̆i- 'mieć zamknięte oczy', p. MŻÉ́" (Bańkowski 2000, t. 2, s. 181). 
shaqqah tajlibu al-taysir)" (Urbańczyk 2012, s. 168), což opětovně navazuje na pověst o navrácení zraku u Měška.

Většina záznamů však pochází z textů napsaných v latině. S ohledem na nejednotný zápis ve středověkých textech, v nichž jsou slovanské hlásky zapisovány latinskými písmeny, a také s ohledem na to, že výslovnost polských výrazů byla různě interpretována cizinci, kteř́i prováděli jejich zápisy, objevuje se mnoho verzí jména Mieszko (Měšek). Nejstarší pocházejí z německých kronik, např. saský kronikář Widunkind z Korbei uvádí verzi Misaca, Gerhard z Augsburgu v Životě sv. Udalryka napsaném v letech 983-993 používal formu Misico (Urbańczyk 2012, s. 168). Rovněž merseburský biskup Thietmar jméno zapisuje jako Misaco nebo - jednou - jako Miseco $^{2}$ a benediktinský mnich Bruno z Querfurtu uvádí tři verze: Misico, Miesico a Mesico. Přičemž ,Ve dvou nejstarších krakovských letopisech je již dvouslabičná forma jména Mesco/Mesko, která byla použita také Gallem Annonymem (Mescho)" (Urbańczyk 2012, s. 168).

Rovněž Jan Niecisław Ignacy Baudouin de Couertenay, který svůj příspěvek o Měškovi zveřejnil v časopise „Kwartalnik Historyczny”, popisoval podobu Mieszko jako zkrácenou formu jména Miecisław/ /Mieczysław. Na něj se odvolává i Jan Gebauer, který tvrdí:

Mezka, Mězka, -y, a také Mezek, -zka, masc.,jm. osobní; z pol. Mieszko, kteréž jest tvar domácky z *müstislavú (podle výkladu E. Kunikova, přelož. od Baudouina v Kwartalniku histiorycznym XII 1898, zvl. otisku str. 11), - myezka kněz polský, pozva na hody krále českého DalC. 33; mezka do Čech vznide tamt.; mezka mnoho zlata mějieše tamt.; od knězě mezky t. 34; Kochan... svým na škodu mezczye tajně radieše t. 35; veze Kochan mezczye kněziu polskému tamt.; Kochan mezczie to da věwěti tamt.; mezka doby pražského hrada tamt.; mezka Oldřicha u věži mějieše t. 33; když mezku silna v zemi uzřěchu t. 34; Oldřich z země mezku vypudi t. 36; - vévoda polský jmenem mezek Pulk. 35 $5^{\text {b }}$, Mezek t. $144^{\text {b }}$ (Gebauer 1970, s. 349).

Polský historik, Jerzy Strzelczyk, se odvolává na další německé prameny, ve kterých se objevují zápisy: Meszigo, Misigo, Misacho,

\footnotetext{
${ }^{2}$ Srov. „Interea Hodo, venerabilis marchio, Miseconem inperatori fidelem tribu-
} tumque usque in Vurta fluvium solventem exercitu petivit collecto"; Thietmar, liber II, cap. 29 (18)
Misicho, příčemž poznamenává, že v polských pramenech jsou také podoby: Mesco, Misko, Mysco i Mesko, i když existují ještě jiné zápisy: Mesecho, Meseco, Mesico, Meszco, Mezcon, Miseco, Misego, Myescho, Myeschco, Myeschko nebo Myeszczo (srov. Strzelczyk $1948)^{3}$. A proto považuje formu Mieszko za původní; také se odolává na starou pověst o Měškovi.

Na základě denárů ražených v době Měška I. polský jazykovědec Stanisław Rospond došel k závěru, že zápis Mesco je druhotný ve vztahu $k$ Misco, který je uvaděn na těchto denárech (Misico). Jeho kořen mis- byl ve středověku ve slovanském názvosloví velmi produktivní (srov. myšk-, mišk-, myš-, miš-), byly od něj tvořeny odvozené formy složených jmen. A proto tvrdí, že se dochovala jenom první část tohoto jména. Později zase, na základě návrhu jiného jazykovědce, Jana Otrębského, došel k závěru, že je to změněná forma druhé části jmen složených s -myst/-mierz, takových, jako Będzimyst, Bolesmyst, Cieszymyst, Dobromyst, Siemomyst, Uniemyst, Kazimierz, Siemierz atd. Jan Otrębski toto jméno spojoval spíše s členem -mierz.

Stojí za to zde také připomenout, že jméno polského knížete bylo interpretováno v kontextu jeho údajného křtu v Německu. Jerzy Dowiat totiž tvrdil, že ,je to [Měškovo - pozn. M.B.] křestní jméno, jméno křest’anského původu - popolštěné jméno řezenského biskupa Michala (Miszka), který podle názoru tohoto badatele pokřtil knížete Polanů v roce 966" (Strzelczyk 1948, s. 67). Ještě vzdálenější je návrh německého slavisty Heindricha Kunstmanna, který se domnívá, že ,jméno Mieszko (Misaco, Mysico atp.) je odvozeno od pojmenování obyvatel balkánské Moesie (Misacus, Mysacus atp.) a př̀edstavuje důkaz původu Měška nebo jeho rodu právě z jihu, z Moesie" (Strzelczyk 1948, s. 68).

${ }^{3}$ Zde je vhodné připomenout, že také v dokladech od Mieszka III. „najdeme několik takových záznamů, což potvrzuje nejistotu jejich transkripce ve středověkých textech: Mesco (rok 1145), Mescho (rok 1145), Misico (rok 1173), ale také Mesico (rok 1173, 1181 a 1188). V pozdějších pramenech toto tajemné jméno bylo mnohokrát „polonizováno” a bylo zapisováno různými způsoby, např. Mieszk Mieszka, Mieszek, Mysko, [...]” (Urbańczyk 2012, s. 168). 
Další komplikaci způsobuje latinský kopie dokumentu Dagome iudex ${ }^{4}$, v němž se objevuje jméno Dagome ${ }^{5}$, které je Ludvíkem Kolankowským vysvětlováno jako pocházející od normanského Dago, Dagon nebo - spíše - od germánského Dagobert (deminutivum Dago), Dagaeus. Tvrdí také, že Měško měl dvě jména: pohanské Mieszko a křestní Dago. Z tohoto důvodu interpretuje slovo Dagome jako spojení dvou jmen: křest’anského a první slabiky jména pohanského. A proto tuto část donace (Dagome iudex) navrhuje číst jako Dago Mesco dux (Kolankowski 1952, s. 155) ${ }^{6}$. S touto verzí nesouhlasí Wojciech Hejnosz, který tvrdí, že poslední slovo bylo Kolankowským špatně interpretováno. Tato část by měla znít takto: Dago Mesco rex, což potvrzují - podle něj - také záznamy od Widukinda a Thietmara (Hejnosz 1954-1956, s. 288), protože i když je dost poškozena a není možné ji jednoznačně přečíst, nemůžeme ji interpretovat až tak dalece jinak (úsek iudex je dost dobře čitelný). V této otázce se nejpravdě-

${ }^{4}$ Dagome iudex je donace hnězdenského knížete, pořízená latinsky v roce 991 , v níž Měšek předává pod papežskou ochranu a vládu sv. Petra svůj stát spolu se všemi př́slušejícími zeměmi. Je to akt tzv. prekaria oblata spočivající v předání vlastnických práv vybrané osobě nebo církevní instituci. Tímto způsobem se prekarista od chvíle donace stává jediným uživatelem majetku, za což se zavazuje platit tzv. svatopetří. Originál donace se nedochoval. Máme $\mathrm{k}$ dispozici jedině shrnutí tohoto aktu, pořízené kardinálem Deusdeditem v letech 1083-1087 a včleněné do dokumentu Collectio canonum, jehož cílem bylo sepsání dějin nezávislosti církve.

${ }^{5}$ Kopie vatikanská: „Item in alio tomo sub Iohanne XV papa Dagome iudex et Ote senatrix et filii eorum: Misicam et Lambertus" (cit. podle: Labuda 1954, s. 207-209). Překlad: „Podobně v jiné knize z časů papeže Jana XV. Dagome, pán, a Ota, paní, a synové jejich: Měšek a Lambert [...]”.

${ }^{6}$ Připomeňme, že již v roce 1846 Wacław A. Maciejowski považoval jméno $D a$ gome za překlad pohanského jména Mieszko (pozdější podoba Mieczystaw) 'slavný $\mathrm{z}$ meče'. Zatímco němečtí badatelé (např. R. Holtzmann v článku Böhmen und Polen in X Jahre. In „Zeitschrift der Vereins für Geschichte Schlesiens” 52, 1918) jméno Dagome považovali za odvozeninu starogermánského slova dagen 'meč', čili Dag, Dago. Keltský rodokmen jména Dagome uznával Władysław Semkowicz (Geneza imienia »Mieszko« $z$ historycznego punktu widzenia. In Inter arma. Zbiór prac ofiarowanych Kazimierzowi Nitschowi, Kraków 1946, s. 67-84), který tvrdil, že toto slovo pochází od keltského (možna illyrského) slova dag 'dobrý'. podobnější verzí zdá vysvětlení Oswalda Balzera, který se domnívá, že chyba kopisty nebo poškozený originální dokument byly př́íčinou chybného přečtení výrazů (možná napsaných dohromady): Ego Mesco dux (srov. Strzelczyk 1948, s. 71), což je typická středověká formule (ego + jméno dárce), která byla uváděna na počatku každého donačního aktu.

Jerzy Dowiat se pokoušel latinskou verzi jména Měška I. přizpůsobit polskému pojmenovávácímu systému tohoto období a došel k závěru, že původně zněla Dzigoma. Tvrdil, že záznam Dagome uvádí celé jeho jméno, jež je zkomoleno podle latinske výslovnosti. V tomto př́padě však chybí jeho vysvětlení nebo apelativní původ, které by mohly potvrdit možnost přečtení písmen $d+a$ jako měkké $d z+i$.

$\mathrm{O}$ vysvětlení původu a významu jména Mieszko se pokoušeli už staří polští kronikáři. V polských kronikách význam tohoto jména jako první (12. st., opisy 14. st.) vysvětloval Gallus Anonymus, jenž konstatoval, jak je uvedeno už výše, že původně Měškovo jméno souviselo s faktem, že se Měšek I. narodil slepý, a proto jeho jméno znamenalo 'zmatek způsobený narozením slepého dítěte' a bylo odvozeno od slova mieszka (srov. současné slovo polské zamieszki 'výtržnost'). Ale již v 15. století se kronikáŕ Jan Długosz domníval, že se jedná spíš o zkomolenou formu jména Mieczsław ${ }^{7}$. Avšak toto jméno nebylo používano v raném středověku, v polštině se objevilo až v XV. století jako zkomolená forma od Miecisław (Myeczslav), a proto je nemůžeme uznat jako původní.

Na Jana Długosze navázal v 16. století Marcin Kromer, který nabídl formu Mieczysław (Miecislauo), což znamenalo 'ten, který mečem získá slávu’. Tím si vymyslel jméno, jež je populární v Polsku dodnes jako oficiální jméno i pro prvního polského knížete, i když se

7 Srov. „Někteří tvrdí, že malého knížete nazývali Mieczysław, což znamená mající býti slavný, a že toto jméno přešlo v Mieszko zdrobnělým oslovením, když byl dítětem. Tak soudíme i my z mnoha důvodů, vezmeme-li v úvahu, že Poláci měli ve zvyku končit jména svých králů a knížat ne na »ko«, ale na »sław«, tvoříce je ve svém jazyce Wodzisław, Bolestaw, Mieczystaw, Przemystaw, Stanisław, Świętostaw". 
nevyskytuje v historických monografiích (stále se zde používá forma Mieszko, která je deminutivní podobou slova Mieczysław, potvrzenou v záznamu z nejstarší polské kroniky od Galla Anonyma). A proto na otázku, která $\mathrm{z}$ výše popsaných verzí je pravdivá, je dnes těžké jednoznačně odpovědět. Historici a jazykovědci prvotní vzor jména knížete Měška I. nadále hledají.

Nemenší pochybnosti vzbuzuje jméno první manželky Měška I., české kněžny Doubravky. I když nevzniklo tolik verzí toho jména jako u jména Mieszko, existují tři jeho variety: Dubrawka, Dobrawa a Dabrówka. Na počátku polští historikové uznali zápis jména první polské kněžny uvedený českým kronikářem Kosmasem, i když existovaly i jiné záznamy provenience německé a polské ${ }^{8}$, protože se toto jméno objevovalo na českém královském dvoře; nepochybovali, že se tam vědělo, jak v českém znění správně pojmenovávat manželku Měška I. Tímto způsobem si zapůjčili a pak adaptovali toto jméno podle polské výslovnosti (Dąbrówka < Doubravka < Dúbravka), jako se totéž ve středověku událo i s českou křest'anskou terminologií. Potom zjistili, že je to záznam možná převzatý z polských letopisů, a proto se obrátili na německé prameny (polské byly také nespolehlivé, o tom dále).

Český kronikár̆ Kosmas, když v 11. stol. psal o smrti polské kněžny, zapsal to jméno jako Doubravka. Je těžké dnes určit, zda je to původní jméno, nebo jeho český ekvivalent, i když se ví, že Kosmas vycházel ze zápisů v hnězdenských letopisech, které byly roku 1038 odvezeny do Čech. Originál letopisů se nedochoval. Máme k dispozici jenom Kosmasův zápis (Doubravka), který nasvědčuje tomu, že v té době bylo jméno Doubravka u českého královského dvora všeobecně používáno. Je také možné, že zápis v hnězdenských letopisech pochází od jejich autora: hnězdenského biskupa českého původu Radima Gaudentia, bratra sv. Vojtěcha, nebo jiného Čecha z jeho okolí.

\footnotetext{
${ }^{8}$ Je třeba zde říci, že české a polské záznamy byly asi stejné. České doklady
} pocházejí z 11. století a polské prameny ze 14. a 15. století. Jedině Thietmarův záznam pochází z 10 . století a značně se liší od ostatních.
Kosmova verze Doubravka má i v českém jazyce svou motivaci. Čeští jazykovědci (např. Václav Machek, Jiří Rejzek) uvádějí, že slovo dúbrava/doubrava pochází z praslovanského slova dąbrava ,les, háj', jemuž v polském jazyce odpovídá výraz dąbrowa. Na tomto základě byla ve středověku prováděna tzv. lidová etymologie jména Doubrava jako lesní žínka, nymfa. Tento název vztahující se k lesu (dubovému) se však častěji vyskytoval jako místní název než jako osobní jméno, navíc až v pozdějších stoletích. Bez ohledu na to je lexikání pole jmen vycházejících z kmene dúb-/doub- v českém jazyce poměrně široké a obsahuje oba slovní základy - doubr- i dobr-: Doubča, Doubravička, Doubravěnka, Doubravce, Dobra, Dobruše, Dobruška, Dobrunka, a odvozeniny: Doubí, Douběnka nebo Duběn$k a$, což může dosvědčovat, že kořeny dúbr-/doubr- a dobr- nesou stejný význam.

Jiný názor má polský jazykovědec Andrzej Bańkowski, jenž staročeský výraz dúbrava (dąbrowa) chápe jako výraz složený z kmene dąbr- a přípony -orva, kmene pocházejícího z praslovanského výrazu dąbrb "tmavý"9 (záměna nosovky [ą] v českém jazyce za dlouhou hlásku [ú] a přesmyčka hlásek [ro], a následně prodloužení a záměna hlásky [o] na [a] v jazycích na jih od Polska). V tom př́ipadě by etymologie tohoto jména byla průhledná. Avšak Thietmar jednoznačně uvádí jinou etymologii: „Dobravou je v jazyce slovanském zvána ta, která se do jazyka německého překládá jako Bona čili dobrá".

\footnotetext{
9 DABROWA, débr-orva compos., *dhümr-arwā 'ciemna niwa', od adi. *dhumr-o-s, prasłow. débrz 'ciemny' (p. DĄB) i sb. *ar-w-a, od ar- 'orać' (p. ORAC, ROLA 1.). Por. łac. arvum 'rola, ziemia orna', adi. arvus 'orny', gr. aroura 'rola' (*arvo-era 'rolna ziemia', por. gr. éraze, érasde 'na ziemię'). Także dъbrorva (z typowym w kompozytach najstarszych osłabieniem wokalizmu pierwszego członu w prasłow.), skąd ukr. dibróva, wcześniej dobrova, dobro(ro)va (haplologia) [...]. Nie przekonuja inne (wszystkie dotychczasowe) próby objaśnień, nie objaśniające najprościej ani znaczenia, ani regularnej repartycji wariantów słowa, jak ta objaśnia: z prasłow. -orva płd. -rava (czes. dubrava, serb.-chorw. dubrava, słowe. dobrava, st.-cs. débrava, skąd i rum. dumbrav ), płn.-zach. -rova (stp. dabrowa XIII), wsch -(o)rova. W toponimii pol. Dabrowa (także zdr. Dąbrowica, Dąbrówka) jest najczęstszą i najżywotniejszą z nazw topograficznych.
} 
I když český kronikář Kosmas zapsal jméno ženy Měška I. jako Doubravka (< dúb), jeho etymologický vývod spojil s apelativem dobrý, protože hagiografové Doubravky zdůrazňovali její činění dobra a Thietmar ji nazval kmotrou Polska, když tvrdil, že se ,ukázala ve skutečnosti taková, jak znělo její jméno", tzn. 'dobrá, ${ }^{10}$. Z tohoto pohledu se původ polského jména Dobrawa (a zdrobnělého Dobraw$k a$ ) zdá srozumitelný a záznam Kosmy nasvědčuje počeštění polského názvu ${ }^{12}$. Na tento aspekt upozornil Tadeusz Lehr-Spławiński, když položil otázku, proč název ,zcela významově jasný pro mluvčího, mající navíc silnou psychologickou oporu v tak četných staropolských jménech, utvořených na základě toho samého kořene dobr-", podlehl „postupně změně na Dąbrówka” (Lehr-Spławiński 1932, s. 104-105), změně na název, který souvisí se staročeským slovem dúbrava, ale ne s českým jménem Dubravka. Odpovědí může být hypotéza Lehra-Spławińského, že antroponymum Dobrawa začalo z polského jazyka mizet, protože bylo vytlačováno slovem Dobrochna, tehdy velmi populární zdrobnělou formou tohoto jména ve Velkopolsku. Potom místo něj byl zaveden název odpovídající české formě tohoto jména Dąbrówka, který však ve 14 . nebo 15 . stol. nebyl již spojován s původním významem výrazu dąbrowa 'tmavá' (např. tmavovlasá), ale s 'dubovým lesem'. Avšak nikoliv etymologie zapřícinila zavedení

Polskie fakty topograficzne i dialektalne popierają hipotetyczne znaczenie pierwotne 'ciemna niwa'. Dąbrową nazywano z reguły las przerzedzony na użytek rolniczy albo pasterski, tzn. niwy, łąki, pastwiska ocienione pozostawionymi na nich starymi drzewami, najcześciej starymi dębami, które najtrudniej wykarczować i najpożyteczniej pozostawić: dla żołędzi służących na karmę świniom. Stąd w końcu, przez późne skojarzenie $\mathrm{z}$ dąb, dąbrowa w nowym znaczeniu 'stary las dębowy' (zamiast stp. dąbie, dębnik itp. w tym znaczeniu) (Bańkowski 2000, d. 1., s. 253-254).

${ }^{10}$ Srov. záznam z Thietmarovy kroniky: „Unde Miseconis, Poleniorum incliti ducis et in superioribus libris ex magna parte signati, residuum explico factum. Hic a Boemia regione nobilem sibi uxorem senioris Bolizlavi duxerat sororem. Quae, sicut sonuit in nomine, apparuit veraciter in re. Dobrawa enim Sclavonice dicebatur, quod Teutonico sermone Bona interpretatur"; liber IV, cap. 55 (35).

${ }^{11}$ Dobrawa nebo Dobrawka má také svůj polský protějšek ve jménu Dobrówka (polská metateze $o r>r o ́, \mathrm{v}$ pozdější době vyslovována [ru]). tohoto názvu do polské historiografie, nýbrž jeho ,polské” znění (srov. Taszycki 1939).

Druhým postupem polských historiků bylo zavedení názvu, který se objevoval v kronikách a letopisech sepsaných ve Velkopolsku a Malopolsku a v německé kronice merseburského arcibiskupa Thietmari merseburgiensis episcopi chronicon. Protože zápis $\mathrm{z}$ tohoto období v polských historických pramenech chybí, obrátili historici pozornost k prvnímu dochovanému zápisu jména Měškovy ženy, a to na formu Dobrawa, která se objevila na stránkách kroniky arcibiskupa Thietmara, jenž žil v asi stejné době jako Doubravka.

Záznamy z polských kronik pochází z doby pozdější. Toto jméno bylo zapisováno různě: Dobrava, Dubrava, Dubrowka, Dubrawka, Dambrowka, Dombrowka, což pouze dokazuje, že způsob zápisu vlastních jmen byl libovolný, např. ve Velkopolské kronice (z první poloviny 13. stol.) se objevují zápisy: Dobrawka a Dobrochna, které mají společný kořen s českým dobr- (srov. Labuda 2012). Nacházejí se také zápisy tohoto jména v letopisu Sędziwoje z Czechła a v Traskově letopisu v podobě: Dobrouca, Dobrovca, Dobravca, které je třeba číst jako Dobrówka, Dobrawka. Podobně v Kuropatnickém rukopisu z první pol. 14. stol. (Dobrouca). V kronice Galla Anonyma Cronica et gesta ducum sive principum Polonorum (psané v letech 1112-1116, opis vznikl kolem r. 1300, Rukopis Heisberský) jsou zápisy různé: Dobrouca, Dobrouka, Dobrauca, ale také: Dambrovca, Dambroucam, Dambrouca. Ještě jinou formu uvádí mladší kopie kroniky Galla Anonyma (kolem r. 1360): Dubrowca, třetí kopie kroniky uvádí také formy: Dubrouca a Dambrowka (srov. Lehr-Spławiński, 1932).

Od 14. století je možné sledovat převahu zápisů jiných než Dobrawa, např. Eugeniuszowský rukopis (rukopis Kroniky Wincentyho Kadłubka) z první pol. 14. stol. uvádí formu: Dambrouca; Katalog krakovských biskupũ z 15. stol.: Dambrowka a Dubrowka; Letopis Velkopolský z tzv. Velké kroniky: Dambrovca; Codex diplomaticus ecclesiae cathedralis necnon Dioeceseos Vilnensis z 14.-15. stol.: Dubrowka. A již v 15. stol. se pravidelně objevují formy Dąbrówka, např. v ko- 
dexu szamotulském, lubińském a królewieckém Malopolského letopisu: Dabrowka, Dambrowka; v kuropatnickém kodexu Malopolského letopisu: Dombrovca vedle Dubrowka; ve vatikánském Kodexu Chigi z XV. století: Dobruwka. A proto můžeme říci, že do poloviny 13. stol. v historických dokumentech je závazná forma Dobrawka, a od druhé poloviny 13. století také Dubrowka, a již v pozdějších rukopisech (14. a 15. stol.) se vyskytuje nová forma: Dambrowca, protože tehdy tato forma Dobrawka začala být pocit'ována jako čechismus a kopisté svévolně měnili českou formu Dubrawka na Dambrowca, Dąbrówka atp. (srov. Labuda 1939-1947, s. 132), čímž ji prrizpůsobovali tehdejšímu systému polského názvosloví (forma Dubrawka byla pravděpodobně zavedena pod vlivem Kosmovy Kroniky české).

O tom, že historici přijali formu Dobrawa jako závaznou, rozhodla skutečnost, že nalezli její zápis v dokumentu polské královny Richezy / Rychsy (nar. kolem r. 993), ženy Měška II., vyhotoveném 7. záŕí 1054 pravděpodobně $\mathrm{v}$ Brauweileru u Kielu, a v zápisech kláštera v Brauweileru z let 1095-1099 (jejich pravost potvrzuje pečet' kielského biskupa Hermanna). Nachází se $\mathrm{v}$ nich název douerauua (Doverava, Dob(e)rawa). „V tomto dokumentu královna po smrti bratra svého knížete švábského Otty uděluje klášteru z Brauweileru celou řadu privilegií [...], a manželce ministeriála Embrichona zmíněnou usedlost v Geldesdorpu" (Labuda 1939-1947, s. 137), proto v něm zmiňuje jméno obdarované: Dobrawa, která s ní pravděpodobně odjela do Německa v r. 1032 nebo 1035. Svědčí to o tom, že v 10. stol. bylo na polském knížecím dvoře užíváno jméno Dobrawa.

Jméno první manželky knížete Měška I. dodnes představuje jednu z největších záhad. Ani jazykovědci, ani historici se nemohou shodnout na jedné verzi jména polské kněžny. Zatím uznávaná (spíš historiky) je verze Dobrawa.

Tyto jména (Doubravka a Měšek) se úplně vyhýbají tradici středověkých dvojčlenných jmen, která kromě označovací funkce plnila také funkci přací, např. jako složenina Boleslav: bole(j) (původní význam 'více, velmi') + sláva - 'člověk, který bude velmi slavný', Mieczysław - miecz + sława ‘člověk, který dobude slávu mečem’ nebo mieć + stawa 'člověk, který bude slavný', Svatopluk - svatý (původní význam 'silný, mocný') + pluk 'člověk, který bude mít silnou rotu vojáků’ atd.

Shrnujíce, můžeme říci, že z hlediska onomastiky není důležité, jak budeme pojmenovávat první polský knížecí pár - Doubravku a Měška: jmény odvozenými od apelativ dobrá nebo mieszek, nebo od jiných. Funkcí vlastního jména je přece označit osobu jako jedince, ne přechovávat apelativní zdroj, i když ten se někdy ve jméně aktualizuje. Zde ukázané různé etymologické výklady měly jen pomoci ukázat pravděpodobné původní znění jmen prvního polského vládce a jeho české mažnelky.

\section{Literatura}

B ánkowski Andrzej, 2000, Etymologiczny stownik języka polskiego, díl 1. a 2.,Warszawa: Wydawnictwo Naukowe PWN

B a ń k ows k i Andrzej, 1989, Imiona przodków Bolestawa Chrobrego u Galla Anonima - Rozważania etymologiczne. „Onomastica” 34, s. 103-138.

D ě t $\mathrm{m}$ a r z Merseburku, 2008, Kronika, přel. B. Neškudla, J. Žytek, Praha: Argo.

D ow i a t Jerzy, 1976, Dubrouka verni ad Miskonem. Geneza zapiski. In Cultus et cognitio. Studia z dziejów średniowiecznej kultury, Warszawa, s. 123-128.

Die Chronik des Bischofs Thietmar von Merseburg und ihre Korveier Überarbeitung, 1935, ed. R. Holtzmann, Manuscripta Germaniae historica. Scriptores rerum Germanicarum, Nova series, Bd. IX, Berlin.

G e b a u e r Jan, 1970, Slovník staročeský, díl II [K-N], Praha: Academia.

H e j n o s z Wojciech, 1954-1956, Z rozważań nad dokumentem »Dagome iudex«, „Slavia Antiqua” V, s. 283-291.

Ko 1 a n k o w s k i Ludwik, 1953, Dagome iudex, „Życie i Myśl”, č. 1-6, s. 155-164.

Kow alski Tadeusz, 1946, Relacja Ibrāhīma Ibn Jakūba z podróży do krajów słowiańskich w przekazie al-Bekrīego. Kraków: Skład Główny w Księgarniach Gebethnera i Wolffa.

K r c h a H., 1885, Dobravka, kněžna polská, „Komenský” VIII.

Kosmova kronika česká, 2012, překlad Karel Hrdina a Marie Bláhová, Praha: Československý spisovatel.

Kronika Thietmara, 1953, wyd. M.Z. Jedlicki, Poznań.

K ü rb is Brygida, 1962, Dagome iudex - studium krytyczne. In Poczatki państwa polskiego. Księga Tysiąclecia, t. II, Poznań: Państwowe Wydawnictwo Naukowe, s. 362-423. 
L a b u d a Gerard, 1939-1947, Dąbrówka czy Dobraw(k)a? Uzupetnienie do dyskusji o poprawne imię żony Mieszka I, „Slavia Occidentalis” 18, s. 126-138, 533.

L a b u d a Gerard, 2012, Pierwsze wieku monarchii piastowskiej, Poznań: Wydawnictwo Nauka i Innowacje.

L a buda Gerard, 1954, Stowiańszczyzna pierwotna. Wybór tekstów, Warszawa: Państwowe Wydawnictwo Naukowe, s. 207-209.

Lehr-S pław iński Tadeusz, 1961, Od piętnastu wieków. Szkice z pradziejów i dziejów kultury polskiej, Warszawa: Pax.

Lehr-S pławiński Tadeusz, 1932, Dąrówka czy Dobrawa?, „Język Polski” 17, s. 104-109.

Ło w mi á s k i Henryk, 1986, Imię chrzestne Mieszka I. In idem, Studia nad dziejami Stowiańszczyzny, Polski $i$ Rusi $w$ wiekach średnich, Poznań: Wydawnictwo Uniwersytetu im. Adama Mickiewicza, s. 286-356.

M a c h e k Václav, 1971, Etymologický slovník jazyka českého, Praha: Academia.

M is hi n Dimitrij, 1996, Ibrahim ibn-Ya'qub at-Turtushi's account on the Slavs from the middle of the tenth century. In Annual of medieval studies at Central European University Budapest (1994/95), s. 184-199.

P t a ś n i k Jan, 1911, Dagome iudex. Przyczynek krytyczny do genezy świętopietrza w Polsce, Kraków: Spółka Wydawnicza Polska.

R e j z e k Jiří, 2001, Český etymologický slovník. Praha: Leda.

S trze lc zy k Jerzy, 1992, Mieszko I. Poznań: Abos.

T a s z y c k i Witold, 1939, A jednak Dabrówka, ,Język Polski” 24, sešit 3., s. 86-88.

U r b a ń c z y k Przemysław, 2012, Mieszko Pierwszy tajemniczy, Toruń: Wydawnictwo Naukowe Uniwersytetu Mikołaja Kopernika.

V o š a h lík o vá Pavla a kol., 2011, Biografický slovník českých zemí. Praha: Libri, sešit 13. s. 345-346.

Z e is s b e r g Heinrich, 1867, Mesico I (Mieczyslaw), der erste christliche Beherrscher der Polen. Wien: Gerold. 